\title{
ПРИРОДА РЕГРЕССНОГО ТРЕБОВАНИЯ КОНТРОЛИРУЮЩИХ ЛИЦ В ДЕЛЕ О БАНКРОТСТВЕ
}

\section{THE NATURE OF THE REGRESS CLAIM OF CONTROLLING PERSONS IN A BANKRUPTCY CASE}

\section{A. Kuznetsov}

Summary. The article examines the nature of the regress claim of the controlling person in a bankruptcy case. The grounds for the occurrence of a regress claim and the procedure for submitting a regress claim are investigated. The position of the judicial authorities on the possibility of including a recourse claim in the register of claims is indicated only in the case of full execution of the judicial act on the involvement of the controlling person to subsidiary liability. The nature of the recourse claim is considered through the prism of subsidiary liability. The author concludes that the regress claim of a controlling person in a bankruptcy case differs from the doctrinal nature of such a claim. It is suggested that the recourse claim has the nature of a refund of unused funds. The article formulates the position that a recourse claim can be sent only in respect of funds received precisely by bringing the controlling person to subsidiary liability. The author comes to the conclusion that the recourse claim does not create a monetary obligation of the debtor to the controlling person and is aimed only at returning unused funds received from the fact of bringing such a person to subsidiary liability.

Keywords: controlling persons, subsidiary liability, recourse claim, nature of liability, illegal behavior, bankruptcy, responsibility of the controlling person.

$\Phi$ едеральный закон от 26.10.2002 N127-Ф3 «О несостоятельности (банкротстве)» (далее - Закон о банкротстве) устанавливает четыре вида ответственности контролирующих лиц, которые закреплены в положениях статей 61.11.-61.13., 61.20.

Исходя из анализа положений указанных статей, можно разделить ответственность контролирующих лиц на два основных вида:

субсидиарная ответственность (ст.ст. 61.11., 61.12.), связанная фактом банкротства юридического лица и переходом на контролирующее лицо, обязательств первоначального должника перед кредиторами (подконтрольного юридического лица); ответственность в виде убытков (ст.ст. 61.13., 61.20.), связанная непосредственно с контролирующим лицом и его личными действиями (бездействиями) (субъективная ответственность).

\author{
Кузнечов Андрей Вячеславович \\ Аспирант, ФГБОУ ВО «Байкальский государственный \\ университет», г. Иркутск \\ kuznec3194@gmail.com
}

Аннотация. В статье рассматривается природа регрессного требования контролирующего лица в деле о банкротстве. Исследуются основания возникновения регрессного требования и порядок предъявления регрессного требования. Указывается позиция судебных органов о возможности включения регрессного требования в реестр требований, только в случае полного исполнения судебного акта о привлечении контролирующего лица к субсидиарной ответственности. Характер регрессного требования рассматривается через призму субсидиарной ответственности. Автором делается вывод, что регрессное требование контролирующего лица в деле о банкротстве отличается от доктринальной природы такого требования. Выдвигается предположение, что регрессное требование имеет природу возврата не использованных денежных средств. В статье формулируется позиция, что регрессное требование может быть направлено, только в отношении денежных средств, полученных именно за счет привлечения контролирующего лица к субсидиарной ответственности. Автор приходит к выводу, что регрессное требование не порождает для контролирующего лица денежного обязательства должника перед ним и направлено лишь на возврат не использованных денежных средств, полученных из факта привлечения такого лица к субсидиарной ответственности.

Ключевые слова: контролирующие лица, субсидиарная ответственность, регрессное требование, природа ответственности, противоправное поведение, банкротство, ответственность контролирующего лица.

Положениями статьи 61.15. Закона о банкротстве установлены права и обязанности лиц, привлекаемых к ответственности.

Пунктом 3 указанной статьи, установлено право на обратное требование (регресса) к должнику по делу о банкротстве.

Исходя из буквального толкования положений статьи 61.15. следует, что регрессное требование возникает, только из субсидиарной ответственности, следовательно, из ответственности, возникшей на основании положений статей 61.11.-61.12.

Таким образом, субсидиарная ответственность контролирующих лиц, установленная за невозможность полного погашения требований кредиторов и за неподачу (несвоевременную подачу) заявления о признании 
должника банкротом, порождает на стороне привлекаемого к ответственности лица, право обратного требования к должнику.

Размер такого регрессного требования зависит от выплаченной суммы и удовлетворяется после всех других требований (включенных в реестр и требований находящихся за реестром требований кредиторов).

Следовательно, исходя из прямого толкования статьи, регрессное требование может быть включено в реестр требований, в том размере, в котором оно оплачено в пользу конкурсной массы.

Вместе с тем, заявить такое требование может лишь лицо, которое в полном объеме исполнило обязанность по возмещению размера субсидиарной ответственности в пользу должника, данное положение подтверждается судебной практикой (Постановление Арбитражного суда Поволжского округа от 25.02.2020 № Ф06-34278/2018 по делу № А65-1797/2016).

Как следствие, размер регрессного требования, так или иначе, равен сумме требований кредиторов включенных в реестр требований в зависимости от особенностей статьи (61.11. или 61.12.), на основании которой контролирующее лицо, привлечено к субсидиарной ответственности.

Хохлов В.А. в отношении определениях регрессных обязательств в доктрине указывает, что «Само понятие «регресс» (вольная интерпретация от лат. regressus «возвратное, обратное движение») указывает на сферу его применения: регрессные обязательства возникают в случаях, когда на должника возлагается долг, ранее уплаченный другим лицом (должником по первичному обязательству).» $[1$, с. 34].

Учитывая изложенное, регрессное требование контролирующего лица, приобретённое в силу привлечения такого лиц к субсидиарной ответственности, носит иную природу, нежели доктринальное регрессное требование.

Это также связано с тем, что природа субсидиарной ответственности контролирующих лиц в деле о банкротстве, также отличается от доктринальной природы субсидиарной ответственности и устанавливается за противоправное поведение, в частности за нарушение обязанности действовать добросовестно и разумно по отношению к кредиторам подконтрольного лица.

Морхат П.М. считает, что «субсидиарная ответственность контролирующего должника лица по обязательствам должника в делах о его банкротстве является особой разновидностью правовой ответственности и по правилам главы III.2 Закона о банкротстве наступает в связи с причинением вреда имущественным правам кредиторов подконтрольного лица.» [2, с. 75].

При этом следует учитывать, что такая обязанность соотноситься с корпоративной обязанностью контролирующего лица действовать в интересах юридического лица добросовестно и разумно, таким образом, закон о банкротстве расширяет корпоративную обязанность контролирующих лиц, распространяя её на кредиторов.

С учетом изложенного, нам необходимо рассмотреть природу регрессного требования в рамках дела о банкротстве через призму субсидиарной ответственности, установленной в Законе о банкротстве.

Гутников О.В. считает, что «...предоставление субсидиарному должнику права регресса против основного должника противоречит как природе гражданско-правовой ответственности, которая предполагает необходимость несения ответственным лицом дополнительных обременений, так и существу фактически складывающихся между сторонами отношений: денежные средства, выплаченные должнику в конкурсную массу, затем могут истребоваться из нее ответственным лицом обратно, что выглядит абсурдным, не говоря уже о том, что фактически у должника никаких средств к моменту предъявления регрессного требования уже не будет и возвращать будет нечего.» [3, с. 54].

По мнению автора, следует учитывать, что право регрессного требования не создает для должника (юридического лица) денежного обязательства перед лицом, привлеченным к субсидиарной ответственности, поскольку, регрессное требование образовалось не в силу наличия каких-либо обязательств между указанными лицами, а в силу противоправных действий (бездействий) контролирующего лица, руководителя. Кроме того, необходимость привлечения к субсидиарной ответственности в деле о банкротстве связана с фактом невозможности удовлетворения требований кредиторов.

Следовательно, регрессное требование, с учетом природы субсидиарной ответственности в рамках дела о банкротстве, имеет не обратный (регрессный) характер, а имеет характеристику возврата не использованных денежных средств, данный вывод основан на следующем.

С учетом положений статьей 15, 4011064 Гражданского кодекса РФ, субсидиарная ответственность является механизмом отнесения имущественных потерь, на дополнительного должника, возникших вследствие неисполнения обязательства основным должником, сле- 
довательно, такая ответственность имеет иные правовые основания и природу возникновения, и требования, сформировавшиеся в рамках субсидиарной ответственности имеют природу гражданско-правовой ответственности и не могут быть долговым обязательством основного должника перед дополнительным.

Фактически регрессное требование сводится к тому, что привлеченное к субсидиарной ответственности лицо, вправе получить не использованные денежные средства обратно после погашения всех требований должника и окончании банкротства, поскольку, субсидиарная ответственность направлена лишь на возмещение имущественных потерь кредиторов и в случае полного возмещения таких потерь, необходимость в остатке денежных средств отпадает. Поскольку, юридическое лицо (должник) не может претендовать на оставшиеся денежные средства, полученные вследствие привлечения контролирующего лица к субсидиарной ответственности за основного должника перед кредиторами, они подлежат возврату, в пользу привлеченного к ответственности лица.

Тот факт, что остатка денежных средств подлежащих возмещению в порядке регресса может и не быть, не отменяет того, что в случае наличия такого остатка он должен быть возвращен, поскольку, конкурсная масса формируется за счет различных механизмов.

Единственным важным обстоятельством, которое не разрешено законодателем и судебной практикой и может вызывать споры, является порядок определения массы денежных средств, из которых будет удовлетворено регрессное требование.

По мнению автора, регрессное требование контролирующего лица, может быть направлено, только на денежные средства, включенные в конкурсную массу, вне- сенные именно за счет субсидиарной ответственности такого лица, а не на иные денежные средства, полученные из иных источников. Такое обстоятельство связано именно с природой субсидиарной ответственности и регрессного требования, как требования связанного с противоправным поведением и необходимостью удовлетворения требований кредиторов, поскольку убытки, возникают не у должника, а у его кредиторов, в виде не исполненных обязательств.

Такой правовой подход, к регрессному требованию контролирующих лиц, является наиболее обоснованным и исходит из природы субсидиарной ответственности и регрессного требования в деле о банкротстве, поскольку противоправное поведение не может порождать у субъекта такого поведения какие-либо позитивные имущественные права. Следовательно, регрессное требование контролирующего лица может быть предъявлено только в рамках дела о банкротстве, предъявление такого требования иным способом, в том числе путем прямого взыскания в рамках гражданско-правового спора, невозможно и нарушало было основополагающие принципы права и позволило бы получить имущественную выгоду, от своего недобросовестного поведения.

Схожая позиция также отражена в Постановлении Первого арбитражного апелляционного суда от 12.03.2020 по делу № А39-10947/2019.

Таким образом, мы установили, что регрессное требование контролирующего лица в деле о банкротстве, не порождает для него денежного обязательства должника, направлено лишь на возврат не использованных денежных средств, полученных из факта привлечения такого лица к субсидиарной ответственности, и может быть рассмотрено только в деле о банкротстве и ни как иначе.

\section{ЛИТЕРАТУРА}

1. Хохлов В.А. Общие положения об обязательствах: учебное пособие. М.: Статут, 2015. 288 с.

2. Морхат П.М. Субсидиарная ответственность в делах о банкротстве как самостоятельная (основная) ответственность контролирующего должника лица за нарушение обязанности действовать добросовестно и разумно по отношению к кредиторам подконтрольного лица // Вестник Арбитражного суда Московского округа. 2019. N4. С. 68-79.

3. Гутников 0.В. Ответственность руководителя должника и иных лиц в деле о банкротстве: общие новеллы и недостатки правового регулирования // Предпринимательское право. 2018. N1. С. 48-60.

○ Кузнецов Андрей Вячеславович ( kuznec3194@gmail.com ).

Журнал «Современная наука: актуальные проблемы теории и практики» 